\title{
On the irrelevance of government debt when taxes are distortionary ${ }^{\text {零 }}$
}

\author{
Marco Bassetto $^{\mathrm{a}, \mathrm{b}, *}$, Narayana Kocherlakota ${ }^{\mathrm{c}, \mathrm{b}, \mathrm{d}}$

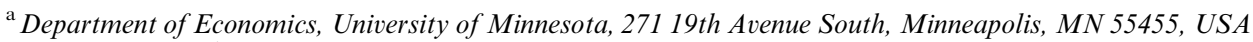 \\ ${ }^{\mathrm{b}}$ Federal Reserve Bank of Minneapolis, Minneapolis, MN 55401, USA \\ ${ }^{\mathrm{c}}$ Department of Economics, Stanford University, Stanford, CA 94305, USA \\ ${ }^{\mathrm{d}}$ National Bureau of Economic Research, Cambridge, MA 02138, USA
}

Received 8 February 2002; received in revised form 13 November 2002; accepted 5 December 2002

\begin{abstract}
We consider a government that can only raise funds by levying distortionary taxes. We allow the government to collect taxes in a given period that are based on incomes earned in previous periods. We show that once we do so, given any debt path, the government can adjust its tax policy so as to attain that debt path without affecting equilibrium allocations or prices.
\end{abstract}

(C) 2003 Elsevier B.V. All rights reserved.

JEL classification: E62; H62; H63

Keywords: Ricardian equivalence; Government debt; Distortionary taxes

\section{Introduction}

In this paper, we consider a government that can only raise funds by levying distortionary taxes. However, we allow the government to collect taxes in a given

\footnotetext{
We thank Mariacristina De Nardi, Bob King and an anonymous referee for useful comments. We acknowledge the support of NSF through Grants \#0095766 (Bassetto) and \#0076315 (Kocherlakota). The views expressed in this paper are those of the authors and not necessarily those of the Federal Reserve Bank of Minneapolis, the Federal Reserve System or the NSF.

*Corresponding author. Department of Economics, University of Minnesota, 271 19th Avenue South, Minneapolis, MN 55455, USA. Tel.: + 1-612-625-4347; fax: + 1-612-624-0209.

E-mail address: bassetto@econ.umn.edu (M. Bassetto).
} 
period that are based on incomes earned in previous periods. ${ }^{1}$ We show that once we do so, given any debt path, the government can adjust its tax policy so as to attain that debt path without affecting equilibrium allocations or prices.

The intuition behind our result is simple. Suppose that the interest rate is 0 . Private agents do not care whether the government sets a $30 \%$ tax on current labor income to be paid now, or a $15 \%$ tax to be paid now and an additional $15 \%$ tax that is based on today's income, but can be paid in the future. While the path of government debt can be changed through such a choice, only the present value of taxes matters for real allocations. For this argument to apply, it is important that households have correct anticipations about the possibly state-contingent future government policy and that they are able to borrow and save at the market interest rate.

There are two main implications of our result. The first is theoretical. It is often said that government financing decisions affect allocations if taxes are distortionary, and do not affect allocations if taxes are lump-sum. Our result shows that this statement is misleading. Financing decisions are irrelevant for any government that can freely adjust the timing of tax payments. The distinction between distortionary and nondistortionary taxes is a red herring. This is especially important if the restriction on the class of admissible tax schedules is viewed only as the result of underlying asymmetric information: to condition future tax payments on past actions, the government does not need any additional information.

The second (related) implication is in reference to the large literature that studies optimal linear taxation (see Chari and Kehoe, 1999). These papers all restrict current taxes to be functions of current incomes. This is without loss of generality in terms of welfare. However, once taxes can be functions of past incomes, these analyses cannot pin down an optimal path of debt.

There is a large literature on debt irrelevance. The first formal statement comes from Barro (1974). If taxes are lump sum and agents are either infinitely lived or part of dynasties linked by operative transfers, Barro proves that both initial debt and the entire evolution path of debt are irrelevant. While lump sum taxes are essential for the first result, we show that they are not for the second part. ${ }^{2}$

The results that are closest to ours stem from generational accounting, an approach advocated by Auerbach et al. (1991, 1994) and Kotlikoff (1992). According to generational accounting, the timing of taxes (and hence debt) is irrelevant; an appropriate analysis of fiscal policy should focus on the present value of taxes paid by different generations. We extend this intuition, and formally establish conditions under which debt irrelevance applies in the presence of distortionary taxes. ${ }^{3}$

\footnotetext{
${ }^{1}$ It is worth mentioning that the dependence of labor income taxes on past incomes is not just a theoretical possibility. For example, in the United States, both social security transfers and welfare payments depend on income histories, and part of the taxes on labor income are postponed by the presence of IRAs and 401(k) plans.

${ }^{2}$ The assumption that agents are infinitely lived or part of dynasties is essential for both results.

${ }^{3}$ In both Auerbach et al. (1994) and Kotlikoff (1999), the authors mention that their approach is still valid even when taxes are distortionary. However, their emphasis is on the accounting procedure, so they mainly focus on characterizing the incidence of distortionary taxes. Accordingly, some of their examples fit
} 
The irrelevance result we obtain bears some similarity to what Chari et al. (1994) show for state-contingent debt: in their environment, when state-contingent capital taxes are allowed, the use of state-contingent debt becomes superfluous.

\section{Main result}

Consider a two-period economy, populated by a continuum of identical households whose preferences are $u\left(c_{1}, n_{1}\right)+u\left(c_{2}, n_{2}\right)$, where $c_{t}$ is consumption in period $t, n_{t}$ is the amount spent working in period $t$, and $u$ satisfies standard assumptions. The production function is such that, for arbitrary $x, x$ units of time spent working produce $x$ units of (perishable) output.

The government uses $g$ units of the private good in period 2 to produce a public good and raises revenues through taxes on labor income. Suppose first that the government imposes a potentially nonlinear tax schedule $\phi_{1}$ on period 1 labor income, and a potentially nonlinear tax schedule $\phi_{2}$ on period 2 labor income. Given these tax schedules, let $R_{1}^{*}$ denote the equilibrium interest rate between periods 1 and $2, n_{t}^{*}$ denote the equilibrium level of labor in period $t$, and $c_{t}^{*}$ denote the equilibrium level of consumption in period $t$. The government debt in this equilibrium (after period 1) is equal to $-\phi_{1}\left(n_{1}^{*}\right)$.

Now, suppose instead that the government can tax period-1 labor income in period 2 as well. Let $\phi_{1 t}$ be the tax rate on period-1 labor income collected in period $t$. If $\phi_{11}+\phi_{12} / R_{1}^{*}=\phi_{1}$, then the household present-value budget constraint at the interest rate $R_{1}^{*}$ is unaffected:

$$
\begin{aligned}
c_{1}+c_{2} / R_{1}^{*} & \leqslant n_{1}+n_{2} / R_{1}^{*}-\phi_{11}\left(n_{1}\right)-\phi_{12}\left(n_{2}\right) / R_{1}^{*}-\phi_{2}\left(n_{2}\right) / R_{1}^{*} \\
& =n_{1}+n_{2} / R_{1}^{*}-\phi_{1}\left(n_{1}\right)-\phi_{2}\left(n_{2}\right) / R_{1}^{*} .
\end{aligned}
$$

Hence, the household budget set is the same at $R_{1}^{*}$. It follows that, under this new government policy, the equilibrium remains unchanged in terms of consumption, labor, and the interest rate.

However, the debt level at the end of period 1 does change: it becomes $-\phi_{11}\left(n_{1}^{*}\right)$. Note that by varying $\phi_{11}$, the government can achieve any level of debt (positive or negative) that it desires. It is exactly in this sense that we mean that debt is irrelevant: given any desired debt level, the government can choose the tax policy so as to achieve that debt level without affecting equilibrium allocations or interest rates.

The result can be summarized as follows. When people are choosing how hard to work, they consider only how the present value of their tax payments changes with respect to labor supply. The government can alter the timing of when it collects the taxes that are based on a particular period's income without affecting this present

(footnote continued)

our conditions for irrelevance, whereas in others irrelevance only holds if the response of agents to changes in the tax policy is neglected. 
value. Hence, by manipulating when it collects taxes, the government can freely adjust its debt without affecting the equilibrium. ${ }^{4}$

\section{Remarks}

We first consider four extensions for the result.

Remark 1. The result generalizes readily to economies with more than two periods.

Remark 2. The result can be readily extended to environments with capital income taxes or consumption taxes.

Remark 3. The result also generalizes easily to economies with multiple types of private agents, whether the type is observable to the government or not.

Remark 4. In settings in which agents have private information, it may be optimal for taxes to depend not just on the agents' observed choices, but also on their reports to a central tax authority (Golosov et al., 2003). Our result can be extended to include these kinds of tax systems. Specifically, let $r_{t} \in R$ be a report that each agent must submit in period $t$; tax collections can now depend on $\left(r_{1}, \ldots, r_{t}\right)$ as well as on $\left(n_{1}, \ldots, n_{t}\right)$. The household's choice problem now includes the optimal choice of $r$. Our result extends directly to this framework.

Remark 5. It is possible to extend the proposition to environments with uncertainty. This extension is trivial in the case of complete markets, but also applies to many incomplete-market settings. As an example, suppose that $g$ can take the values $g_{1}, \ldots, g_{S}$ in period 2. Assume there is an equilibrium in which the government imposes tax schedule $\phi_{t}$ on period- $t$ labor income and let $q_{1}, \ldots, q_{S}$ be the state prices. The household budget constraint is

$$
c_{1}-n_{1}+\phi_{1}\left(n_{1}\right)+\sum_{s=1}^{S}\left[q_{s}\left(c_{2}(s)-n_{2}(s)+\phi_{2}\left(n_{2}(s), s\right)\right)\right] \leqslant 0 .
$$

When markets are complete, the government does not affect this constraint if it collects taxes in period-1 income according to a schedule $\phi_{11}$ in period 1 and a

\footnotetext{
${ }^{4}$ In the case of lump-sum taxes, Sargent (1987) emphasizes the connection between Ricardian equivalence and the Modigliani-Miller theorem. In Modigliani and Miller (1958), the timing of dividend payments is irrelevant for the present value of a firm. In the case of Ricardian equivalence with lump-sum taxes, the timing of taxes is irrelevant for the present value of government spending, which is what needs to be financed. In our environment, taxes are distortionary, but the government has access to a sufficiently rich tax structure to be able to change the timing of tax collections without affecting asset prices. In this case, the timing of taxes can be changed with no consequences on the present value of government spending.
} 
potentially random schedule $\phi_{12}$ in period 2 , subject to

$$
\phi_{11}\left(n_{1}\right)+\sum_{s=1}^{S} q_{s} \phi_{12}\left(n_{1}, s\right)=\phi_{1}\left(n_{1}\right) \quad \forall n_{1} .
$$

As a consequence, the first-period surplus can be changed arbitrarily without affecting the allocation of consumption and leisure, nor the equilibrium prices. The government has also many degrees of freedom which can be used to alter the way its deficit/surplus depends on the realization of $g$, as in Chari et al. (1994), without any effect on real variables.

When markets are incomplete, a similar result applies as long as the tax policy does not change the span of consumption and leisure allocations a household can attain. Formally, if a household is restricted to choose allocations so that $\left\{c_{2}(s)-\right.$ $\left.n_{2}(s)-\phi_{2}\left(n_{2}(s), s\right)\right\}_{s=1}^{S} \in D$, with $D$ being a linear space, a sufficient condition for the government not to change the real allocation is to choose $\phi_{12}$ so that (1) holds and $\left\{\phi_{12}\left(n_{1}, s\right)\right\}_{s=1}^{S} \in D$ for all possible values of $n_{1}$. A simple case arises when there is uncertainty and only risk-free borrowing and lending is allowed. In this case, the government can alter the path of (risk-free) debt without affecting the real allocation by choosing $\phi_{11}$ and $\phi_{12}$ subject to (1) and to the additional constraint that $\phi_{12}$ is independent of the realization of $g$.

Our result does have two significant limitations.

Remark 6. The version of Ricardian Equivalence proved by Barro (1974) contemplates variations in the level of initial debt. In his setting with lump-sum taxes, such variations had no effect on the set of competitive equilibria. This result is not true in our setting with distortionary taxes. We assumed no initial level of debt; changing the initial level of debt would change the equilibrium set. Intuitively, any extra initial debt must be paid off using distortionary taxes, and this will cause a welfare loss.

Remark 7. Our result hinges on the fact that all agents are alive in all periods. Debt is relevant in overlapping-generations economies, although it is possible that the same equilibrium allocation and price system may be consistent with different tax functions and paths of debt, as emphasized by the literature on generational accounting. ${ }^{5}$

\section{Conclusions}

The main contribution of this paper is theoretical. We find that the path of government debt generally does not affect real allocations, even when taxes are

\footnotetext{
${ }^{5}$ For results on debt irrelevance in overlapping-generations economies, see also Ghiglino and Shell (2000, 2003).
} 
distortionary. The key ingredient to our result is that the tax collections in period $t$ must be allowed to depend on past incomes.

Is it possible for tax systems to exhibit this kind of history dependence in practice? One difficulty is that the government may not have sufficient enforcement mechanisms to deter agents from spending the resources they would need to meet future tax obligations. This is presumably one reason for the pervasive use of withholding.

However, these enforcement concerns do not prevent governments from conditioning current transfers on past outcomes. (Indeed, at least in the United States, social security transfers do exhibit this kind of history dependence.) If we make this weaker assumption instead, then we can still obtain a local debt irrelevance result, as opposed to the global theorem that we obtain in the paper.

\section{References}

Auerbach, A., Gokhale, J., Kotlikoff, L., 1991. Generational accounts: a meaningful alternative to deficit accounts. In: Bradford, D. (Ed.), Tax Policy and the Economy, Vol. 5. MIT Press, Cambridge, pp. 55-110.

Auerbach, A., Gokhale, J., Kotlikoff, L., 1994. Generational accounting: a meaningful way to evaluate fiscal policy. Journal of Economic Perspectives 8, 73-94.

Barro, R.J., 1974. Are government bonds net wealth? Journal of Political Economy 82, 1095-1117.

Chari, V.V., Kehoe, P., 1999. Optimal fiscal and monetary policy. In: Benhabib, J., Woodford, M. (Eds.), Handbook of Macroeconomics, Vol. 1C. North-Holland, New York, pp. 1671-1745.

Chari, V.V., Christiano, L., Kehoe, P., 1994. Optimal fiscal policy in a business cycle model. Journal of Political Economy 102, 617-652.

Ghiglino, C., Shell, K., 2000. The economic effects of restrictions on government budget deficits. Journal of Economic Theory 94, 106-137.

Ghiglino, C., Shell, K., 2003. The economic effects of restrictions on government budget deficits: imperfect private credit markets. Economic Theory 21, 399-421.

Golosov, M., Kocherlakota, N.R., Tsyvinski, A., 2003. Optimal indirect and capital taxation. Review of Economic Studies 70, 569-587.

Kotlikoff, L., 1992. Generational Accounting: Knowing Who Pays, and When, For What We Spend. Free Press, New York.

Kotlikoff, L., 1999. From deficit delusion to the fiscal balance rule: looking for an economically meaningful way to assess fiscal policy. In: Auerbach, A., Kotlikoff, L., Leibfritz, W. (Eds.), Generational Accounting Around the World. The University of Chicago Press, Chicago, pp. 9-30.

Modigliani, F., Miller, M.H., 1958. The cost of capital, corporation finance and the theory of investment. American Economic Review 48, 261-297.

Sargent, T.J., 1987. Dynamic Macroeconomic Theory. Harvard University Press, Cambridge. 